\title{
Composting of olive processing wastes and tomato stalks together with sewage sludge or dairy manure
}

\author{
F. Şevik ${ }^{1} \cdot \dot{\text { İ. }} \operatorname{Tosun}^{1}(1) \cdot$ K. Ekinci ${ }^{2}$
}

Received: 27 August 2015/Revised: 12 January 2016/Accepted: 8 February 2016/Published online: 7 March 2016

(C) Islamic Azad University (IAU) 2016

\begin{abstract}
In this study, composting of olive pomace from three-phase oil production system, sewage sludge, dairy manure, and tomato stalks were carried out. The effects of carbon/nitrogen ratio on decomposition rate of composting were investigated with constant free air spaces of composting mixtures. Composting process was carried out in the aerobic reactors made of stainless steel which were monitored for 32 days. Temperature-controlled feedback system was operated based on the Rutgers strategy. Temperature, moisture, organic matter, $\mathrm{pH}$, electrical conductivity total carbon, total nitrogen, ammonium nitrogen and nitrate nitrogen, total phosphorus as well as potassium were monitored during the composting process. In addition, mass and volume changes of the mixtures were determined. The highest degree of decomposition was determined for the mixture (carbon/nitrogen ratio of 20) based on the dry matter loss where the maximum amount of sewage sludge was used. On the other hand, maximum decomposition occurred at a carbon/nitrogen ratio of 23 for mixtures containing dairy manure. The increase in the use of olive pomace in mixtures had adverse effects on the decomposition process. The stabilization process in the mixture containing dairy manure lasted shorter than the mixtures containing sewage sludge.
\end{abstract}

Keywords $\mathrm{C} / \mathrm{N}$ ratio $\cdot$ Free air space $\cdot$ Heavy metal . Mass loss · Olive stone structure $\cdot$ Rutgers strategy

İ. Tosun

ismailtosun@sdu.edu.tr

1 Department of Environmental Engineering, Suleyman Demirel University, 32260 Isparta, Turkey

2 Department of Agricultural Machinery and Technologies Engineering, Suleyman Demirel University, Isparta, Turkey

\section{Introduction}

Olive oil processing wastes cause major environmental problems. Ninety-five percent of world olive oil production is carried out in Mediterranean countries (Spain, Italy, Greece, Syria, Turkey, and Tunisia) (Aktas et al. 2001). High amounts of olive processing wastes olive pomace (OP) and olive mill wastewater (OMW) (for three-phase systems) as well as two-phase olive mill waste (TPOMW) (for two-phase systems) are produced over a short growing season (Roig et al. 2006). It was estimated that $1,676,000$ tons of olives produced (TurkStat 2013) in 2013 in Turkey led to 921,800 tons of by-product of OP (Şevik 2014). On the other hand, sewage sludge and animal manure also lead to many environmental problems, especially pollution of groundwater and surface water. It was estimated that approximately 226 million tons of animal manure (Şevik 2014) were produced due to the number of $12,386,337$ dairy and cattle in 2013 in Turkey (TurkStat 2013). Biological processes such as composting and vermicomposting have been widely recognized in converting organic materials into nutrient-rich fertilizer and soil conditioner (Lim et al. 2015a). Composting method for olive oil processing wastes such as OP and TPOMW were suggested since they are more practical and have a greater economical value compared with other disposal methods, while it is also reported that compost quality is increased when co-composted with animal manure (Roig et al. 2006). Addition of amendments and bulking agents to the initial compost mixture in addition to the main material can balance $\mathrm{C} / \mathrm{N}$ ratio and porosity (Kumar et al. 2010). Therefore, cocomposting of OP with sewage sludge and animal manure is crucial from a waste management perspective. Fernández et al. (2010) and Sánchez-Arias et al. (2008) achieved fruitful results through co-composting sewage sludge with 
plant and animal based wastes. Hygienization as well as reduction in volume and the amount of sludge through composting are achieved and thus it enables the use of stabilized compost as a nutrient source in agriculture (Doublet et al. 2011). Addition of materials to improve free air space (FAS) of the initial mixture may bring about composting process to the optimum levels in terms of moisture content, $\mathrm{C} / \mathrm{N}$ ratio, particle size, and $\mathrm{pH}$ while also ensuring a high rate of decomposition of organic matter (Ingelmo et al. 2012).

Although wood chips (Franke-Whittle et al. 2014), olive leaves and rice husk (Muktadirul Bari Chowdhury et al. 2014), pumice (Wu et al. 2014a), recyclable plastic (Zhou et al. 2014), dry leaves (Sudharsan Varma and Kalamdhad 2015), mushroom residue (Hu et al. 2015), rubber wood sawdust (Farah Nadia et al. 2015) usually were used to maintain proper air space in the initial mixture, chopped tomato stalks have not yet been utilized in composting. Wei et al. (2014) have studied the effect of biochar addition on the quality of tomato stalk and chicken manure composting. Biochar addition had a greater impact on the physico-chemical properties and microbial community diversity in comparison with peat bog and zeolite. Therefore, the objective of this study was to investigate the cocomposting of OP, tomato stalks together with sewage sludge or dairy manure at different $\mathrm{C} / \mathrm{N}$ ratios at certain FAS value. Process parameters were evaluated during the composting of these wastes, which are commonly found at both national and regional levels. This study was carried out in the composting laboratory of Department of Agricultural Machinery and Technologies Engineering, Suleyman Demirel University, Isparta, Turkey, during the period of March 2014-April 2014.

\section{Materials and methods}

\section{Composting materials}

This study was carried out using OP, dairy manure (DM), sewage sludge (SS), and chopped tomato stalks (TS). OP was received from Taris Olive and Olive Oil Agricultural Sales Cooperatives Union in Aydın province. SS was obtained from wastewater treatment plants in Isparta province. DM and TS was provided from an agricultural farm in Isparta province. TS was chopped down to $2-3 \mathrm{~cm}$ by a stationary chopper. The main characteristics of four raw materials (OP, DM, SS, and TS) are reported in Table 1. Values were given on a dry weight basis excluding the moisture content which was on a wet weight basis. Based on Table 1, it can be stated that organic matter content of OP was high; SS and DM had high initial moisture content, electrical conductivity of TS was high and heavy metal
Table 1 Physico-chemical properties of composting materials used in the experiments

\begin{tabular}{lllll}
\hline Parameter & OP & SS & DM & TS \\
\hline $\mathrm{MC}(\%)$ & 4.26 & 75.89 & 82.28 & 20.77 \\
$\mathrm{OM}(\%)$ & 94.88 & 74.20 & 86.58 & 77.86 \\
$\mathrm{pH}$ & 6.7 & 6.1 & 8.6 & 7.9 \\
$\left.\mathrm{EC}(\mathrm{dS} \mathrm{m})^{-1}\right)$ & 0.8 & 5.6 & 5.6 & 7.4 \\
$\mathrm{TC}(\%)$ & 48.86 & 43.89 & 42.05 & 35.04 \\
$\mathrm{TN}(\%)$ & 1.15 & 4.04 & 1.57 & 2.23 \\
$\mathrm{C} / \mathrm{N}$ & 42.49 & 10.86 & 26.78 & 15.71 \\
$\mathrm{FAS}(\%)$ & 30.00 & 6.50 & 17.50 & 60.00 \\
$\mathrm{BD}\left(\mathrm{kg} \mathrm{l}^{-1}\right)$ & 0.67 & 0.23 & 0.14 & 0.25 \\
$\mathrm{TP}\left(\mathrm{mg} \mathrm{kg}^{-1}\right)$ & 784 & 5890 & 4948 & 1142 \\
$\mathrm{~K}(\%)$ & 0.37 & 0.27 & 1.64 & 1.76 \\
$N H_{4}^{+}-N^{-1}\left(\mathrm{~m} \mathrm{~kg}^{-1}\right)$ & 69 & 1912 & 250 & 530 \\
$N O_{3}^{-}-N\left(\mathrm{mg} \mathrm{kg}^{-1}\right)$ & 136 & 148 & 151 & 1127 \\
$\mathrm{~Pb}\left(\mathrm{mg} \mathrm{kg}^{-1}\right)$ & 2.6 & 25.2 & 3.0 & 3.8 \\
$\mathrm{Cd}\left(\mathrm{mg} \mathrm{kg}^{-1}\right)$ & 0.7 & 0.8 & 0.3 & 0.4 \\
$\mathrm{Cr}\left(\mathrm{mg} \mathrm{kg}^{-1}\right)$ & 10.5 & 34.6 & 5.1 & 19.1 \\
$\mathrm{Cu}\left(\mathrm{mg} \mathrm{kg}^{-1}\right)$ & 12.0 & 98.4 & 49.9 & 67.4 \\
$\mathrm{Ni}\left(\mathrm{mg} \mathrm{kg}^{-1}\right)$ & 5.5 & 29.4 & 6.9 & 11.8 \\
$\mathrm{Zn}\left(\mathrm{mg} \mathrm{kg}^{-1}\right)$ & 24.8 & 751.7 & 172.3 & 67.9 \\
\hline
\end{tabular}

$M C$ moisture content, $O M$ organic matter, $E C$ electrical conductivity, $T N$ total nitrogen, $T C$ total carbon, $T P$ total phosphorous, $K$ potassium, $B D$ bulk density, $\mathrm{NH}_{4}^{+}-\mathrm{N}$ ammonium nitrogen, $\mathrm{NO}_{3}^{-}-\mathrm{N}$ nitrate nitrogen

concentrations of SS were higher than that of the other materials.

\section{Experimental setup}

The mixing ratios and initial $\mathrm{C} / \mathrm{N}$ ratios of mixtures are presented in Table 2. The values of FAS calculated based on density of materials and particles (Adhikari et al. 2009) were adjusted to $32 \%$ in all mixtures. Ranges of FAS from 30 to $35 \%$ were proposed by Haug (1993) in order to provide sufficient aerobic conditions for decomposition of several materials. The mixture containing SS was named as OST while that which consists of DM was named as ODT. OT was the mixture of OP and TS thereby yielding an initial $\mathrm{C} / \mathrm{N}$ ratio of 42 . Fixed FAS values and different $\mathrm{C} / \mathrm{N}$ ratios of each mixture were calculated by using solver addin function of the Microsoft Excel ${ }^{\mathrm{TM}}$ taking into consideration the FAS $(6.50-60.00 \%)$ and $\mathrm{C} / \mathrm{N}$ ratios (10.86-42.49) for each raw material.

Seven-identical cylindrical stainless steel reactors, each with an effective volume of 1001 with inner diameter of $47.3 \mathrm{~cm}$ and height of $57.0 \mathrm{~cm}$ were used in the experiment (Fig. 1). The reactors had perforated stainless steel floors with hole sizes of $4 \mathrm{~mm}$ (diameter) at a height of 
Table 2 Composting mixtures (dry basis) and set values of $\mathrm{C} / \mathrm{N}$ ratios

\begin{tabular}{llllllll}
\hline & OST-1 & OST-2 & OST-3 & ODT-1 & ODT-2 & ODT-3 & OT \\
\hline OP $(\%)$ & 52.26 & 81.16 & 96.68 & 5.00 & 47.36 & 92.18 & 98.83 \\
SS $(\%)$ & 32.70 & 12.41 & 1.51 & - & - & - & - \\
DM $(\%)$ & - & - & - & 67.07 & 36.79 & 4.75 & - \\
TS $(\%)$ & 15.04 & 6.43 & 1.81 & 27.93 & 15.85 & 3.07 & 1.17 \\
C/N & 20 & 30 & 40 & 23 & 30 & 40 & 42 \\
\hline
\end{tabular}

OST-1, OST-2, OST-3: Mixtures which have olive pomace, sewage sludge and tomato stalks at the ratio of C/N 20, 30 and 40, respectively. ODT-1, ODT-2, ODT-3: Mixtures which have olive pomace, dairy manure and tomato stalks at the ratio of $\mathrm{C} / \mathrm{N} 23,30$ and 40, respectively. OT: Mixture which has olive pomace and tomato stalks at the ratio of $\mathrm{C} / \mathrm{N} 42$
Fig. 1 Experimental setup used for composting

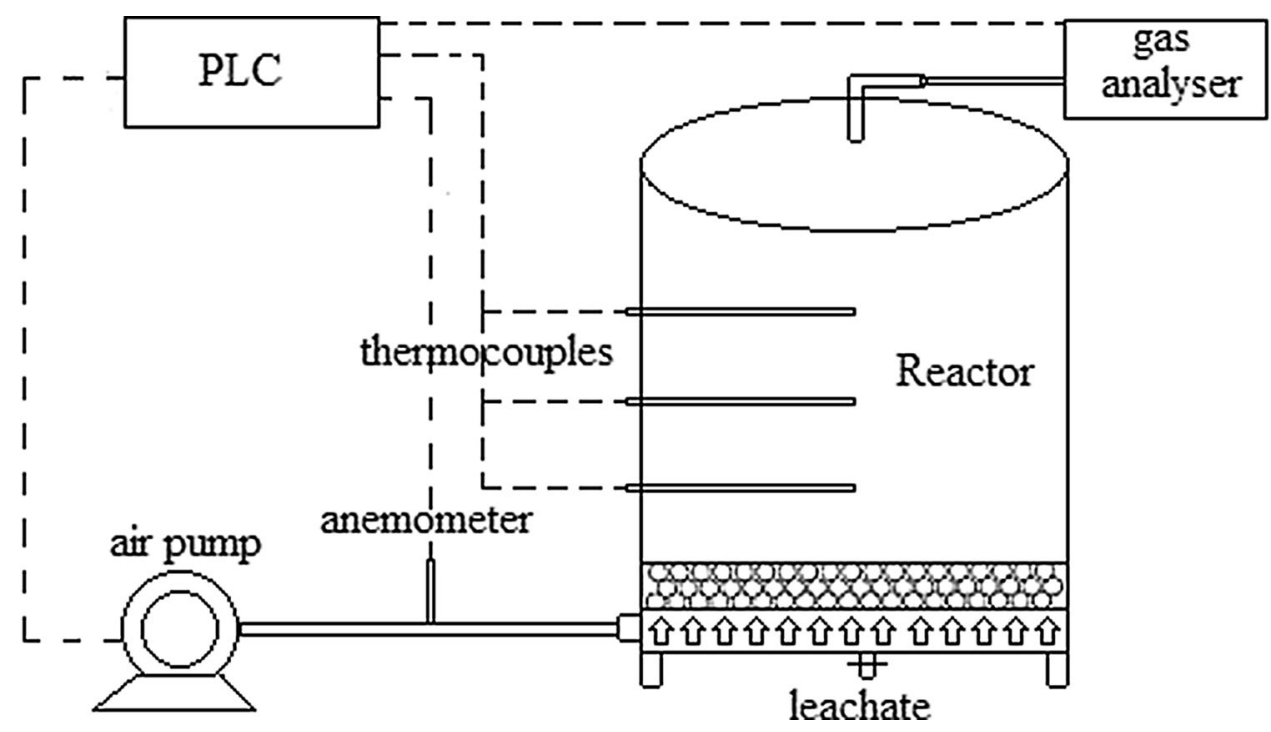

$13 \mathrm{~cm}$ from the bottom and 40 percent opening for providing a plenum for air distribution under the compost. The bottom sides of reactors were fabricated with a reverse conic shape, and a $50-\mathrm{mm}$ stainless steel valve was mounted to collect leachate. Reactors were connected to a metal frame with a bearing to discharge compost material for remixing. Air was supplied to the reactor through a straightway single clapper connected to $50-\mathrm{mm}$ PVC pipe. Side walls and lids of the reactors were insulated with glass wool material. K type thermocouples with a diameter of $3 \mathrm{~mm}$ and $35 \mathrm{~cm}$ length were inserted into each composting reactor equipped with three ports to facilitate temperature at three levels of 10.0, 27.0, and $44.0 \mathrm{~cm}$ above the perforated floor. Control of aeration fans, solenoid valves, and pumps in the laboratory composting systems as well as data acquiring and logging were performed using a PLC (Schneider M258). Air flow supplied to the reactors by fans $(0.25 \mathrm{~kW})$ was measured by a hot wire anemometer (QVM62.1 Siemens), and the results of the measurements were transmitted to the PLC unit. Variable speed drive (Schneider, ATV12H037M2) connected to PLC through ADC modules was used to obtain required fan speeds corresponding to volumetric air flow rate $\left(\mathrm{Q}, \mathrm{m}^{3} \mathrm{~h}^{-1}\right)$ calculated by multiplying velocity with the measured by pipe area. Once volumetric air flow rate input was made to the interface, PLC unit calculated the required fan frequency to provide the optimum flow rate according to the data obtained from the hot wire anemometer.

Feedback control of temperature was maintained by Rutgers aeration strategies (Finstein et al. 1986). Fans were operated in on/off mode when the compost temperature (T) was less than or equal to set point temperature $\left(T_{\mathrm{sp}}\right)$ to regulate airflow and to allow temperature increase. This stage was characterized with on/off time and volumetric airflow rate $\left(\mathrm{Q}_{\min }, \mathrm{m}^{3} \mathrm{~h}^{-1}\right)$ to meet minimum requirements for oxygen and air movement. Aeration rates were adjusted throughout the course of the experiment at this stage. The on/off mode was chosen when $T \leq T_{\mathrm{sp}}$. The fan turned on to provide cooling when the temperature rose above the predetermined value $\left(T_{\mathrm{sp}}\right)$ of $60{ }^{\circ} \mathrm{C}$ (Ekinci et al. 2004) with a differential of $0.4{ }^{\circ} \mathrm{C} . Q_{\max }$ was continuously 
applied by the controller to cool down the compost mass when $T>T_{\mathrm{sp}}$.

\section{Analytical methods}

Composting experiments lasted for 32 days. Mixing was performed on the 7th and 14th days of composting. Duplicate compost samples were taken at the beginning, on the 7th and 14th days and the end of the composting process for physical and chemical analysis. Moisture content of fresh samples was determined after the samples were dried at $70 \pm 5{ }^{\circ} \mathrm{C}$ for 3 days, and organic matter content of dry samples was analyzed after incinerating the samples at $550{ }^{\circ} \mathrm{C}$ as recommended by the US Department of Agriculture and the US Composting Council (USCC 2002). pH and EC of the fresh samples were extracted by shaking at $180 \mathrm{rpm}$ for $20 \mathrm{~min}$ at a solid/water ratio of 1:10 (w/v) and were measured using pH and EC meters (Models WTW pH 720 and WTW Multi 340i), respectively. TC and TN content were analyzed via elemental analyzer (Vario MACRO CN Elemental analyzer). TP was analyzed by the stannous chloride method using a spectrophotometer (Model DR 5000) after nitric acid-perchloric acid digestion, and also heavy metal $(\mathrm{Cd}, \mathrm{Cr}, \mathrm{Cu}, \mathrm{Zn}, \mathrm{Ni}$, and $\mathrm{Pb})$ concentrations were analyzed by the nitric acid-perchloric acid digesting procedures (APHA 1998), and measured using ICP-MS (Model NexION 300X, Perkin Elmer). Concentration of $\mathrm{K}$ was analyzed using Fast Sequential Atomic Absorption Spectrometer (VARIAN, AA240FS Model). $\mathrm{NH}_{4}^{+}-$ $\mathrm{N}$ and $\mathrm{NO}_{3}^{-}-\mathrm{N}$ were determined via DR 5000 spectrophotometer after the samples were extracted with $2 \mathrm{M}$ $\mathrm{KCl}$ (Mulvaney 1996). BD $\left(\mathrm{kg} \mathrm{l}^{-1}\right)$ variation was determined by dividing the total dry weight of material to total material volume in each reactor. Change $(\%)$ in dry matter $\left(\Delta_{\mathrm{DM}}\right), \mathrm{OM}\left(\Delta_{\mathrm{OM}}\right), \mathrm{TC}\left(\Delta_{\mathrm{C}}\right), \mathrm{TN}\left(\Delta_{\mathrm{N}}\right), \mathrm{C} / \mathrm{N}$ ratio $\left(\Delta_{\mathrm{C} / \mathrm{N}}\right), \mathrm{TP}\left(\Delta_{\mathrm{P}}\right), \mathrm{K}\left(\Delta_{\mathrm{K}}\right), \mathrm{NH}_{4}^{+}-\mathrm{N}\left(\Delta_{\mathrm{NH}_{4}^{+}-\mathrm{N}}\right)$ and $\mathrm{NO}_{3}^{-}-\mathrm{N}\left(\triangle_{\mathrm{NO}_{3}^{-}-\mathrm{N}}\right)$ was calculated based on initial and final values of dry matter and their corresponding concentrations. For example, the change $(\%)$ in $\mathrm{TC}\left(\Delta_{\mathrm{C}}\right)$ was calculated as follows:

$\Delta_{C}(\%)=\left(1-\left[\frac{m_{d}(\theta) \cdot T C(\theta)}{m_{d}(0) \cdot T C(0)}\right]\right) 100$

where $m_{d}(0)$ and $m_{d}(\theta)$ are the compost dry mass $(\mathrm{kg})$ at initial and final times, respectively. TC $(0)$ and TC $(\theta)$ are the TC concentrations at initial and final time, respectively.

All data concerning $\Delta_{\mathrm{DM}}, \Delta_{\mathrm{OM}}, \Delta_{\mathrm{C}}, \Delta_{\mathrm{N}}, \Delta_{\mathrm{C} / \mathrm{N}}, \Delta_{\mathrm{P}}, \Delta_{\mathrm{K}}$, $\Delta_{\mathrm{NH}_{4}^{+}-\mathrm{N}}$, and $\Delta_{\mathrm{NO}_{3}^{-}-\mathrm{N}}$ were submitted for statistical analyses using Minitab (Minitab Inc., USA) for ANOVA. The mean and standard deviations of the two replicates were reported for all measured parameters. Tukey test was

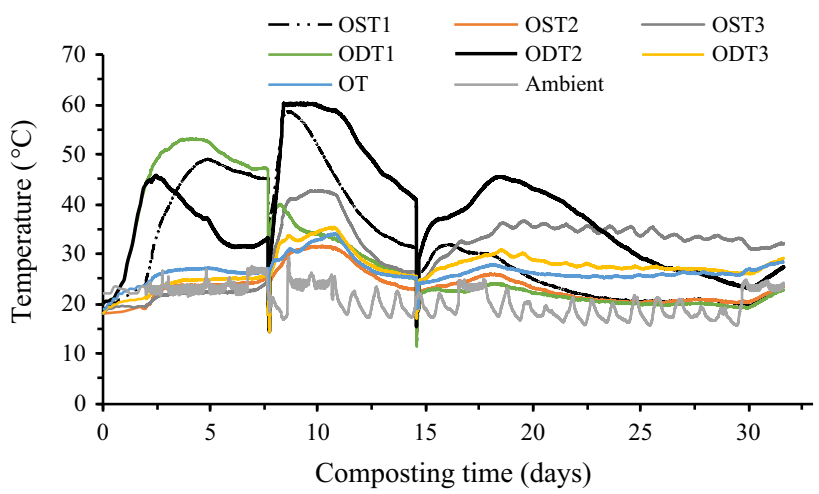

Fig. 2 Temperature profiles of all reactors during composting process

performed to compare the differences. Statistical significance was defined as $P<0.05$.

\section{Results and discussion}

\section{Temperature pattern}

The temperatures in the reactor were measured at three different locations and temperature changes in the midpoint are presented in Fig. 2. While the highest recorded temperature for OT was $35^{\circ} \mathrm{C}$, the highest temperature for the mixture consisting of SS was obtained for OST-1 having the highest sludge ratio with the initial $\mathrm{C} / \mathrm{N}$ ratio of 20 . The mixture with the initial $\mathrm{C} / \mathrm{N}$ ratio of 30 (ODT-2) among the mixtures consisting of DM yielded the highest temperature.

Temperature rose very quickly right after manual mixing on the 7th day of composting and reached a higher level in comparison with that of the previous peak due to the deterioration of the compacted structure by the remixing process. However, no dramatic temperature increment was recorded after the remixing on the 14th day of composting except for ODT-2. The maximum temperature reached in the reactors, the time to reach maximum temperatures and the number of days on which they stayed $55^{\circ} \mathrm{C}$ are given in Table 3. It could be stated that the measured temperature in OST-1 and ODT-2 reached $\geq 55{ }^{\circ} \mathrm{C}$, which is required to kill pathogens (Bernal et al. 2009). Despite the potential of ODT-2 to reach a higher temperature $\left(60.3{ }^{\circ} \mathrm{C}\right)$, high-flow ventilation fan kicked into provide evaporative cooling to control temperature at set value.

The results showed that the temperature development of OST-2, OST-3, ODT-3, and OT mixtures was not sufficient. Poor temperature development could be due to high OP content in initial composition of aforementioned mixtures. Similar effects were observed in the study of Fernández et al. (2010) for the composting olive mill wastes 
Table 3 The maximum temperature reached in the reactors, the time to reach maximum temperatures, and the number of days on which they stayed $\geq 55{ }^{\circ} \mathrm{C}$

\begin{tabular}{|c|c|c|c|c|c|c|c|}
\hline & OST-1 & OST-2 & OST-3 & ODT-1 & ODT-2 & ODT-3 & OT \\
\hline The maximum temperature reached $\left({ }^{\circ} \mathrm{C}\right)$ & 58.6 & 33.4 & 48.6 & 53.1 & 60.3 & 39.1 & 35.0 \\
\hline The time to reach maximum temperatures, days & 8.57 & 10.06 & 9.60 & 3.68 & 9.18 & 10.49 & 10.74 \\
\hline The number of days stayed $\geq 55^{\circ} \mathrm{C}$, days & 1.41 & - & - & - & 3.24 & - & - \\
\hline
\end{tabular}

with cattail biomass with mixing ratio of 73 and $27 \%$ cattail biomass (dry basis), and the highest temperature measured was approximately $43{ }^{\circ} \mathrm{C}$.

\section{Moisture content}

Moisture contents of the mixtures changed due to the results of organic matter decomposition, mass loss, ventilation, ambient humidity and condensation in the headspace of reactors during composting. In composting, coarse and fine waste materials usually require moisture content in the range of 70-75 and 55-65\%, respectively (Lim et al. 2016; Wu et al. 2014b). Although the set value of initial moisture content of the mixtures was planned as $60 \%$ w.b. in this study, they varied due to the low moisture-holding capacity of OP resulting from the presence of the structural component of the olive stone. Therefore, while the ratio of $\mathrm{OP}$ in the mixtures increased, thus increasing initial $\mathrm{C} / \mathrm{N}$ ratio, the initial moisture contents of OST-1, OST-2, and OST-3 varied as $61.1,53.5$, and $48.5 \%$, respectively, while those of ODT-1, ODT-2, and ODT-3 varied as 74.7, 65.6 , and $53.0 \%$, respectively. It can be concluded that increasing the ratio of $\mathrm{OP}$ in the mixtures decreased the initial and final moisture contents of the mixtures (Fig. 3). As can be seen from Table 4, although the decline of final moisture content of mixtures was expected, the results put forth that there was no significant change or even a partial increase in the final moisture content in some reactors. This phenomenon could be attributed to the fact that

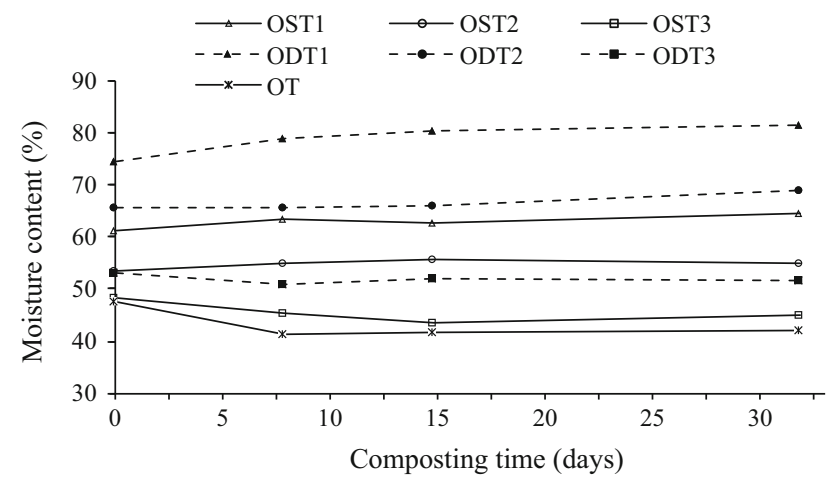

Fig. 3 Changes in moisture content during composting condensation within the headspace of the reactor accumulated moisture in the upper layer of composting and humidity of ambient air was transferred to the compost matrix by the aeration system. According to Tosun (2003), when dry mass loss due to the rate of decomposition of organic matter was less than water loss from composting, an increase in the final moisture content of the mixture could be observed. A strong relationship between the initial and final moisture contents of mixtures was correlated $\left(R^{2}=0.989\right)$. The highest dry matter loss $\left(\Delta_{\mathrm{DM}}\right)$ occurred for ODT-1 with $32 \%$ (Tables 4, 5).

\section{Organic matter content}

The organic matter contents of the mixtures were high due to organic matter contents of the materials used. The initial and final organic matter contents increased with the increase in the ratio of OP in the mixtures. The results indicated a strong relationship $\left(R^{2}=0.959\right)$ between the initial and final organic matter contents. A significant change in the level of organic matter for the mixtures, OST-2, OST-3, ODT-3, and OT was not observed due to the high olive stone structure of OP. On the other hand, ODT-1 and ODT-2, which were high in DM content and OST-1 containing high SS had a significant decline in the final organic matter content (Fig. 4). Organic matter losses $\left(\Delta_{\mathrm{OM}}\right)$ were calculated for ODT-1 $(35.0 \%)$, OST-1 (22.7\%), and ODT-2 (21.2\%) (Tables 4, 5). Rihani et al. (2010) reported that it was difficult to degrade OP and TS by microorganisms due to the structure of cellulose and lignin content. This is because cellulose provides strength over the cell walls, whereas lignin acts as a protective barrier with impermeability and immunity to prevent an attack from the microorganisms (Loow et al. 2015). Organic matter decomposition occurred usually in the first 15 days of composting.

\section{pH and electrical conductivity}

$\mathrm{pH}$ influences the growth and development of microorganisms (Muktadirul Bari Chowdhury et al. 2013). Although the optimum $\mathrm{pH}$ ranges from 5.5 to 8.0 , microbial activity also continued between 6.7 and 9.0. Most of 
Table 4 Physico-chemical properties of initial and final stage of composting process

\begin{tabular}{|c|c|c|c|c|c|c|c|}
\hline & OST-1 & OST-2 & OST-3 & ODT-1 & ODT-2 & ODT-3 & OT \\
\hline \multicolumn{8}{|l|}{$\mathrm{MC}(\%)$} \\
\hline Initial & 61.1 & 53.5 & 48.5 & 74.7 & 65.6 & 53.0 & 47.5 \\
\hline Final & 64.4 & 55.1 & 45.1 & 81.6 & 69.1 & 51.5 & 41.9 \\
\hline \multicolumn{8}{|l|}{ OM (\%) } \\
\hline Initial & 85.3 & 89.1 & 94.0 & 83.5 & 86.0 & 93.6 & 92.9 \\
\hline Final & 80.5 & 89.6 & 94.1 & 80.1 & 83.8 & 93.6 & 91.7 \\
\hline \multicolumn{8}{|l|}{$\mathrm{pH}$} \\
\hline Initial & 6.0 & 6.1 & 6.5 & 8.9 & 8.9 & 8.2 & 6.9 \\
\hline Final & 8.5 & 8.4 & 8.2 & 8.7 & 8.7 & 9.0 & 8.4 \\
\hline \multicolumn{8}{|c|}{$\mathrm{EC}\left(\mathrm{dS} \mathrm{m} \mathrm{m}^{-1}\right)$} \\
\hline Initial & 3.8 & 2.0 & 1.0 & 4.0 & 4.0 & 1.4 & 0.7 \\
\hline Final & 2.5 & 1.6 & 0.7 & 4.6 & 3.3 & 1.0 & 0.9 \\
\hline \multicolumn{8}{|l|}{$\mathrm{C} / \mathrm{N}$} \\
\hline Initial & 20.00 & 30.00 & 40.00 & 23.00 & 30.00 & 40.00 & 41.28 \\
\hline Final & 17.10 & 23.19 & 29.36 & 18.70 & 24.86 & 34.56 & 34.13 \\
\hline \multicolumn{8}{|c|}{$\mathrm{BD}\left(\mathrm{kg} \mathrm{l}^{-1}\right)$} \\
\hline Initial & 0.30 & 0.40 & 0.45 & 0.16 & 0.20 & 0.37 & 0.45 \\
\hline Final & 0.31 & 0.42 & 0.40 & 0.15 & 0.20 & 0.37 & 0.43 \\
\hline \multicolumn{8}{|c|}{$N H_{4}^{+}-N\left(\mathrm{mg} \mathrm{kg}^{-1}\right)$} \\
\hline Initial & 129 & 61 & 26 & 34 & 29 & 15 & 14 \\
\hline Final & 42 & 13 & 11 & 16 & 13 & 10 & 9 \\
\hline \multicolumn{8}{|c|}{$N O_{3}^{-}-N\left(\mathrm{mg} \mathrm{kg}^{-1}\right)$} \\
\hline Initial & 135 & 115 & 110 & 353 & 305 & 258 & 175 \\
\hline Final & 169 & 133 & 146 & 580 & 395 & 279 & 200 \\
\hline \multicolumn{8}{|c|}{$\mathrm{TP}\left(\mathrm{mg} \mathrm{kg}^{-1}\right)$} \\
\hline Initial & 3100 & 1797 & 549 & 4623 & 3410 & 852 & 515 \\
\hline Final & 3516 & 1749 & 752 & 6111 & 3870 & 870 & 551 \\
\hline \multicolumn{8}{|l|}{$\mathrm{K}(\%)$} \\
\hline Initial & 0.79 & 0.62 & 0.50 & 1.13 & 1.17 & 1.08 & 0.59 \\
\hline Final & 0.85 & 0.60 & 0.54 & 1.38 & 1.27 & 1.07 & 0.60 \\
\hline
\end{tabular}

the composting materials were in this $\mathrm{pH}$ range, so the $\mathrm{pH}$ was usually not a major factor. However, it was an important parameter for the control of ammonia losses (Bernal et al. 2009). Changes of $\mathrm{pH}$ in all reactors during the experiment are shown in Fig. 5. Since the $\mathrm{pH}$ of raw materials was between 6.1 and 8.6 , consequently the initial $\mathrm{pH}$ of the mixtures varied. The final $\mathrm{pH}$ values in all the reactors (average 8.6) ended up to be above 8.0. Although $\mathrm{pH}$ decreased in some reactors due to the formation of $\mathrm{CO}_{2}$ and organic acids (Sharma et al. 1997; Lim et al. 2011), it increased again during the process. Ammonia formation occurs as a consequence of ammonification of organic nitrogen due to intense microbial activity and organic matter degradation during the early stage of composting; consequently, the dissolution of ammonia leads to the formation of ammonium and an increase in $\mathrm{pH}$ (SánchezMonedero et al. 2001). In addition, the increase of $\mathrm{pH}$ could be attributed to degradation of short-chain fatty acids (Lim et al. 2014).

EC indicated the presence of soluble salts in the compost mixture. EC reflects the salinity of an organic amendment, in which high salt concentration may cause phytotoxicity (Shak et al. 2014). EC values vary depending on the type of olive oil wastes and use of porous materials (Muktadirul Bari Chowdhury et al. 2013). EC values measured during the composting process in all mixtures are shown in Fig. 6. As can be seen from the figure, EC values varied according to the type and mixing ratios of starting materials. The initial and final EC values decreased as the amount of OP with the lowest EC values among the raw 

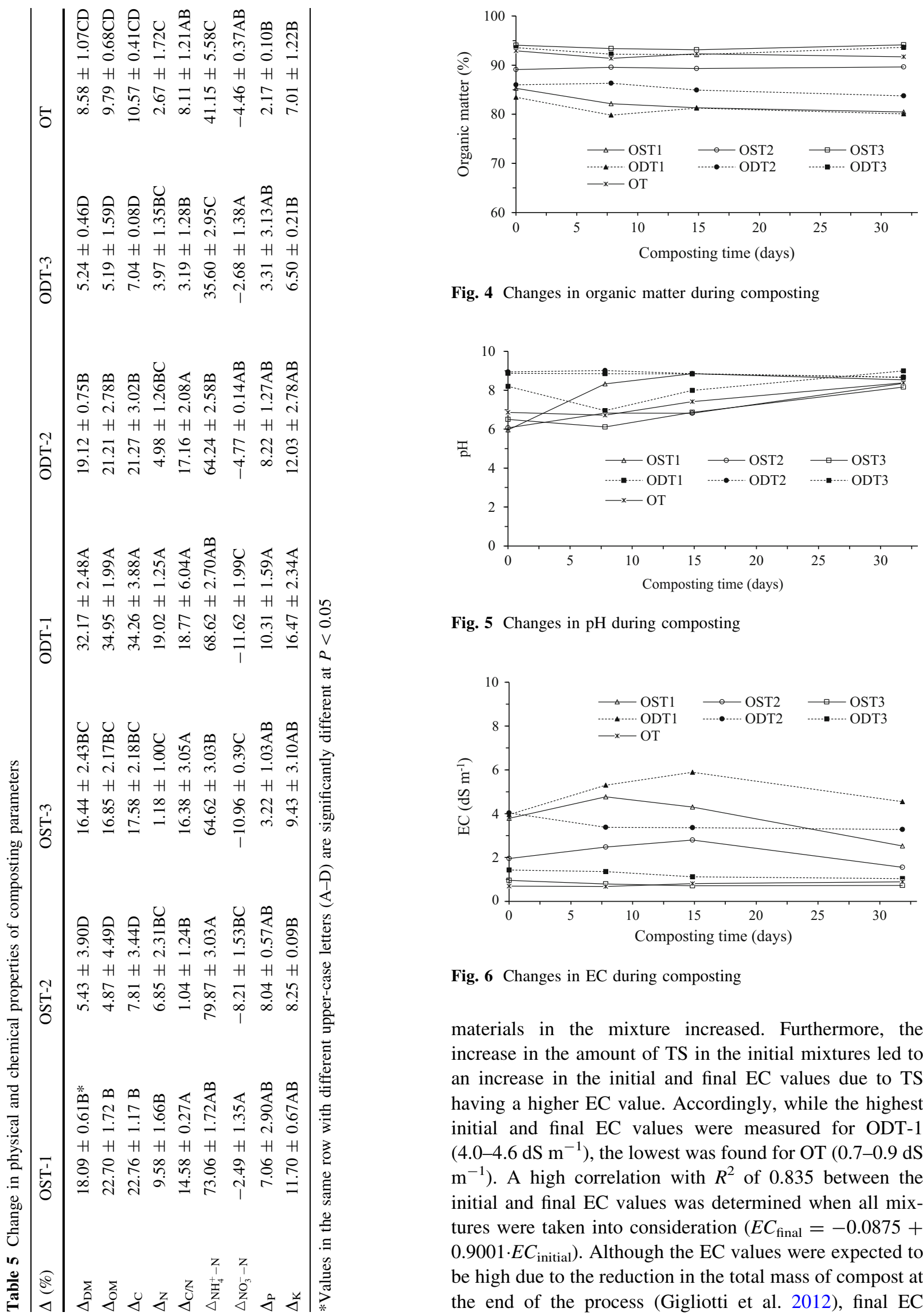

Fig. 4 Changes in organic matter during composting

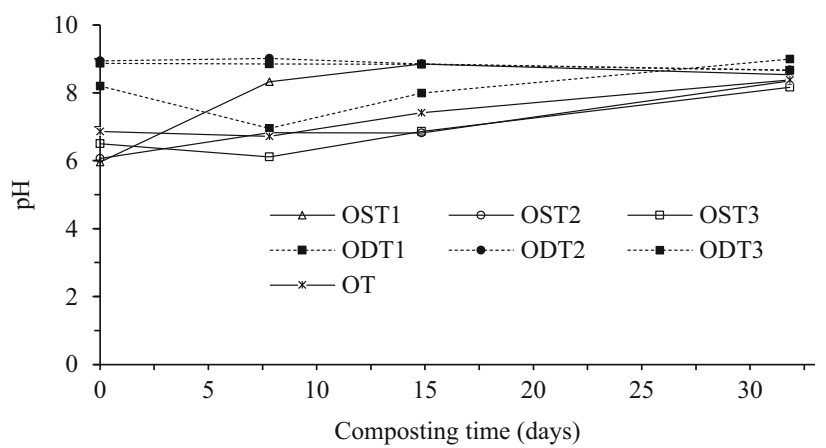

Fig. 5 Changes in $\mathrm{pH}$ during composting

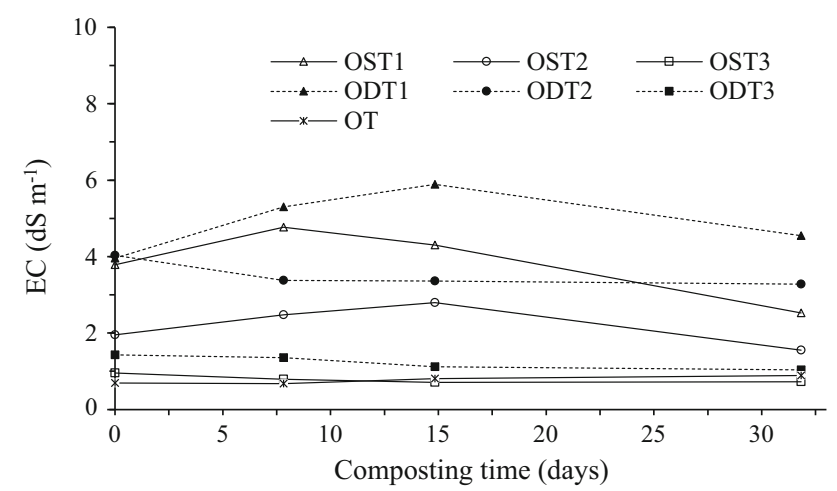

Fig. 6 Changes in EC during composting

materials in the mixture increased. Furthermore, the increase in the amount of TS in the initial mixtures led to an increase in the initial and final EC values due to TS having a higher EC value. Accordingly, while the highest initial and final EC values were measured for ODT-1 $\left(4.0-4.6 \mathrm{dS} \mathrm{m}^{-1}\right)$, the lowest was found for OT $(0.7-0.9 \mathrm{dS}$ $\mathrm{m}^{-1}$ ). A high correlation with $R^{2}$ of 0.835 between the initial and final EC values was determined when all mixtures were taken into consideration $\left(E C_{\text {final }}=-0.0875+\right.$ $\left.0.9001 \cdot E C_{\text {initial }}\right)$. Although the EC values were expected to be high due to the reduction in the total mass of compost at the end of the process (Gigliotti et al. 2012), final EC 
values were low in some cases because of the washing effects resulting from the addition of water to compost matrix (Paredes et al. 2002; Abid and Sayadi 2006; Hachicha et al. 2009; Makni et al. 2010).

\section{$\mathrm{C} / \mathrm{N}$ ratio}

$\mathrm{C} / \mathrm{N}$ ratios were measured at the beginning and end of the composting process (Table 4). Since OP had the highest $\mathrm{C} / \mathrm{N}$ ratio among the raw materials, the increase in the amount of $\mathrm{OP}$ in the initial mixtures led to an increase in the initial $\mathrm{C} / \mathrm{N}$ ratios. $\mathrm{C} / \mathrm{N}$ ratios in all reactors decreased to the range of 17.1-34.6 at the end of process. These values were consistent with the values determined for TPOMW composting (Sellami et al. 2008). Carbon content of the compost decreased as the degradation process continued due to carbon loss in the form of $\mathrm{CO}_{2}$ emission and the nitrogen content increased, thus eventually leading to a decrease in $\mathrm{C} / \mathrm{N}$ ratios of the mixtures (Raj and Antil 2011). The highest change in $\mathrm{TC}\left(\Delta_{\mathrm{C}}\right)$ and $\mathrm{TN}\left(\Delta_{\mathrm{N}}\right)$ existed for ODT-1 with 34.3 and $19.0 \%$, respectively, thereby leading to the highest reduction in $\mathrm{C} / \mathrm{N}\left(\Delta_{\mathrm{C} / \mathrm{N}}\right)$ for ODT-1 with $18.8 \%$ (Tables 4, 5). Even though the final $\mathrm{C} / \mathrm{N}$ ratio is considered to be indicators of stability of the compost, this parameter is not a good indication due to substantial variations in the raw material properties (Muktadirul Bari Chowdhury et al. 2013).

\section{Ammonium nitrogen and nitrate nitrogen}

The initial and final $\mathrm{NH}_{4}^{+}-\mathrm{N}$ values are listed in Table 4. The $\mathrm{NH}_{4}^{+}-\mathrm{N}$ contents of all the mixtures at the end of experiment decreased. The highest change in $\mathrm{NH}_{4}^{+}-\mathrm{N}\left(\triangle_{\mathrm{NH}_{4}^{+}-\mathrm{N}}\right)$ was calculated for OST-2 with $80.0 \%$ (Tables 4,5 ). Similarly, Gao et al. (2010) determined that $\mathrm{NH}_{4}^{+}-\mathrm{N}$ contents of compost mixtures decreased at the end of experiment (62 days) for chicken manure and sawdust composting. Bernal et al. (1998) conducted composting of sewage sludge, cotton waste, maize straw, olive mill wastewater, pig slurry, poultry manure, sweet sorghum bagasse, and city refuse and found that the final $\mathrm{NH}_{4}^{+}-\mathrm{N}$ content of composting of sewage sludge + maize straw + olive mill wastewater as $661 \mathrm{mg} \mathrm{kg}{ }^{-1}$. The resultant $\mathrm{NH}_{4}^{+}-\mathrm{N}$ content for the remainder of the mixtures was lower than $400 \mathrm{mg} \mathrm{kg}^{-1}$, which is proposed by Zucconi and de Bertoldi (1987). A strong relationship between the initial and final $\mathrm{NH}_{4}^{+}-\mathrm{N}$ content of mixtures was examined $\left(R^{2}=0.901\right)$.

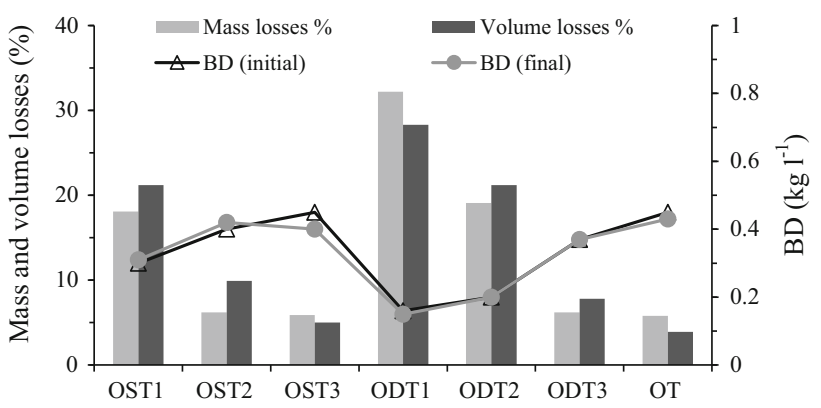

Fig. 7 Bulk density and reduction of volume and mass at initial and final

Table 4 presents the initial and final $\mathrm{NO}_{3}^{-}-\mathrm{N}$ content of mixtures. Since TS had the richest $\mathrm{NO}_{3}^{-}-\mathrm{N}$ content among the raw materials, the initial and final $\mathrm{NO}_{3}^{-}-\mathrm{N}$ contents of ODT-1 were higher than those of the other mixtures. An increase was observed in the $\mathrm{NO}_{3}^{-}-\mathrm{N}$ content of all mixtures at the end of the experiment. Furthermore, the highest change in $\mathrm{NO}_{3}^{-}-\mathrm{N}\left(\triangle_{\mathrm{NO}_{3}^{-}-\mathrm{N}}\right)$ was calculated for ODT-1 with $-11.6 \%$ (Tables 4,5 ). Likewise, Rasapoor et al. (2009) found that $\mathrm{NO}_{3}^{-}-\mathrm{N}$ content of final compost made from municipal wastes increased at the end of the experiment. Regression analysis between the initial and final $\mathrm{NO}_{3}^{-}-\mathrm{N}$ content of the mixtures yielded a strong relationship $\left(R^{2}=0.915\right)$.

\section{Total phosphorous and potassium}

TP indicates the agronomic potential for crop production because phosphorus is an important nutrient required for photosynthesis, energy transfer within plants as well as for good flowering and fruit growth (Lim et al. 2015b). TP values at the beginning and end of the composting process are listed in Table 4. The increase in the amount of OP and the decrease in the amount of SS led to a decrease in the TP values in the mixtures. The TP values of all the mixtures at the end of the experiment increased. Regression analysis between the initial and final TP values put forth a strong relationship $\left(R^{2}=0.981\right)$. The final TP values in this study were slightly lower than those $(0.53-0.85 \%)$ reported by Hachicha et al. (2009) for exhausted olive cake + poultry manure + olive mill wastewater composting. This could be attributed to the differences in TP concentrations of raw materials used in the compost.

Table 4 presents the initial and final $\mathrm{K}$ content of mixtures. The results showed that final $\mathrm{K}$ concentrations of all 
Fig. 8 The relationship between mass and volume losses and the ratio of materials used in the mixtures

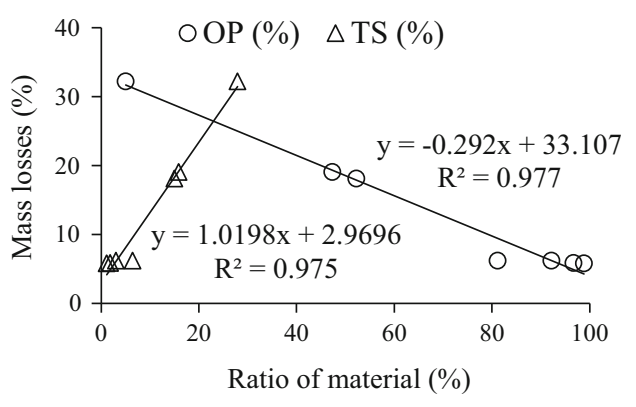

Table 6 Heavy metal content in the final composts

\begin{tabular}{|c|c|c|c|c|c|c|c|c|}
\hline & Turkish regulation (OG 2014) & OST-1 & OST-2 & OST-3 & ODT-1 & ODT-2 & ODT-3 & OT \\
\hline $\mathrm{Pb}\left(\mathrm{mg} \mathrm{kg}^{-1}\right)$ & 150 & 1.30 & 0.90 & 0.60 & 0.90 & 0.70 & 0.50 & 9.20 \\
\hline $\mathrm{Cd}\left(\mathrm{mg} \mathrm{kg}^{-1}\right)$ & 3 & 1.30 & 0.90 & 0.60 & 0.90 & 0.70 & 0.50 & 1.80 \\
\hline $\mathrm{Cr}\left(\mathrm{mg} \mathrm{kg}^{-1}\right)$ & 350 & 35.20 & 10.60 & 13.40 & 19.30 & 11.90 & 14.30 & 24.50 \\
\hline $\mathrm{Cu}\left(\mathrm{mg} \mathrm{kg}^{-1}\right)$ & 450 & 73.60 & 31.50 & 23.20 & 83.60 & 47.70 & 21.50 & 31.50 \\
\hline $\mathrm{Ni}\left(\mathrm{mg} \mathrm{kg}^{-1}\right)$ & 120 & 22.80 & 11.80 & 8.90 & 16.90 & 13.20 & 9.30 & 15.20 \\
\hline $\mathrm{Zn}\left(\mathrm{mg} \mathrm{kg}^{-1}\right)$ & 1100 & 307.00 & 127.10 & 48.20 & 211.80 & 106.80 & 40.30 & 54.00 \\
\hline
\end{tabular}

the mixtures increased. The similar trend was observed from the study of Rasapoor et al. (2009). Regression analysis between the initial and final $\mathrm{K}$ values of the mixtures yielded a strong relationship $\left(R^{2}=0.948\right)$.

\section{Change of compost mass and volume}

BD values of mixtures at the initial and final stages of composting process are shown in Fig. 7. Although BD is expected to increase at the end of the composting process, decrease in these values for OST-3, ODT-3, and OT was recorded depending on the amount of OP used in the mixtures. Farah Nadia et al. (2015) reported that the decrease in BD values of the finished compost may be due to significant changes in mass and volume of the compost mixtures. Breitenbeck and Schellinger (2004) stated that the reduction in the volume of compost due to the degradation of organic matter during composting may be due not only to weight loss but also the existence of the smaller particles as a result of the deterioration of the structure of organic compounds.

Reduction of mass and volume of mixtures at the initial and final stages are given in Fig. 7. It was observed as a result of the figure analysis that mass and volume losses took place in close proximity. Recorded mass and volume losses in all mixtures in descending order can be listed as ODT-1, ODT-2, OST-1, OST-2, ODT-3, OST-3, and OT. This sequence also put forth the increasing and decreasing share of OP and TS in the mixtures, respectively. In other words, the rates of decomposition increased with increasing share of TS in the mixtures and the increase in the amount of OP in the mixtures reduced the decomposition rates as shown in Fig. 8. High correlations between mass and volume losses and the ratio of materials used in the mixtures were determined with regression parameters (slope and intercept values) and the coefficient of determination.

\section{Heavy metal content of composts}

Heavy metal contents of the finished compost are summarized in Table 6. The most abundant heavy metal was $\mathrm{Zn}$, but all values were below those put forth by Turkish regulations (OG 2014). Final heavy metal concentrations of all OST mixtures were higher than those of ODT and OT mixtures due to the presence of SS in their compositions. Final heavy metal contents were in accordance with the ratio of raw materials used in the initial mixtures and were 
shown to increase due to the loss of mass that occurs during composting. Many works on composting put forth that heavy metal concentrations of raw materials and the type of composting systems were reported to be of great importance (Zorpas and Loizidou 2008; Rihani et al. 2010). Fernández et al. (2010) determined final $\mathrm{Zn}$ and $\mathrm{Cu}$ concentrations of 154 and $79 \mathrm{mg} \mathrm{kg}^{-1}$, respectively, for the composting olive mill wastes (38\%, dry basis), sewage sludge $(44 \%)$ with cattail biomass $(18 \%)$. In this study, final $\mathrm{Zn}$ and $\mathrm{Cu}$ concentrations were measured as 127.10 and $73.60 \mathrm{mg} \mathrm{kg}^{-1}$.

\section{Conclusion}

Compostability potential of olive pomace, sewage sludge, and dairy manure with tomato stalks as porous material at different $\mathrm{C} / \mathrm{N}$ ratios at certain FAS value was evaluated based on temperature change, organic matter content, and mass and volume losses. The mixtures could be summarized based on organic matter losses in descending order as: ODT-1 (35.0\%), OST-1 (22.7\%), and ODT-2 $(21.2 \%)$; dry matter losses: ODT-1 (32.2\%), ODT-2 (19.1\%), and OST-1 (18.1\%); volume losses: ODT-1 (28.3\%), ODT-2 (21.2\%), and OST-1 (21.2\%). Accordingly, the best performance was obtained from ODT-1 with $\mathrm{C} / \mathrm{N}$ ratio of 23 . On the other hand, OST-1 and ODT-2 with the similar SS and DM ratios in the mixture also had similar decomposition levels. These mixtures (OST-1, ODT-1, and ODT-2) reached thermophilic temperature levels. The increase in the amount of OP used in the mixtures had adverse effects due to the olive stone structure. On the other hand, the increase in the TS ratio of the mixtures had a positive effect due to its porous structure. High correlations between mass and volume losses and the ratio of materials used in the mixtures were determined. Results showed that when the share of OP in the mixture was lower than $50 \%$ based on dry basis, the use of SS and DM in the mixtures yielded better composting results. Heavy metal values of compost obtained were below the national standards. In conclusion, disposal of olive oil processing wastes with the DM and the SS through composting could be considered as a good alternative.

Acknowledgments The authors wish to thank Suleyman Demirel University Scientific Research Projects Coordination Unit for sup- porting the research project 3815-YL1-13 under which this work was financed.

\section{References}

Abid N, Sayadi S (2006) Detrimental effect of olive mill wastewater on the composting process of agricultural wastes. Waste Manag 26:1099-1107

Adhikari BK, Barrington S, Martinez J, King S (2009) Effectiveness of three bulking agents for food waste composting. Waste Manag 29(1):197-203

Aktas ES, Imre S, Ersoy L (2001) Characterization and lime treatment of olive mill wastewater. Water Res 35:2336-2340

APHA (1998) Standard methods for the examination of water and wastewater, 20th edn. American Public Health Association, Washington

Bernal MP, Navarro AF, Sánchez-Monedero MA, Roig A, Cegarra J (1998) Influence of sewage sludge compost stability and maturity on carbon and nitrogen mineralization in soil. Soil Biol Biochem 30(3):305-313

Bernal MP, Alburquerque JA, Moral R (2009) Composting of animal manures and chemical criteria for compost maturity assessment: a review. Bioresour Technol 100:5444-5453

Breitenbeck GA, Schellinger D (2004) Calculating the reduction in material mass and volume during composting. Compost Sci Util 12:365-371

Doublet J, Francou C, Poitrenaud M, Houot S (2011) Influence of bulking agents on organic matter evolution during sewage sludge composting; consequences on compost organic matter stability and $\mathrm{N}$ availability. Bioresour Technol 102:1298-1307

Ekinci K, Keener HM, Michel FC, Elwell DL (2004) Modeling composting rate as a function of temperature and initial moisture content. Compost Sci Util 12(4):356-364

Farah Nadia O, Xiang LY, Lie LY, Chairil Anuar D, Mohd Afandi MP, Azhari Baharuddin S (2015) Investigation of physicochemical properties and microbial community during poultry manure co-composting process. J Environ Sci 28:81-94

Fernández FJ, Sánchez-Arias V, Rodríguez L, Villaseñor J (2010) Feasibility of composting combinations of sewage sludge, olive mill waste and winery waste in a rotary drum reactor. Waste Manag 30(10):1948-1956

Finstein MS, Miller FC, Strom PF (1986) Waste treatment composting as a controlled system. In: Rehm HJ, Reed G (eds) Biotechnology 8:363-398, VCH Verlagsgesellschaft: Weinheim

Franke-Whittle IH, Confalonieri A, Insam H, Schlegelmilch M, Körner I (2014) Changes in the microbial communities during co-composting of digestates. Waste Manag 34(3):632-641

Gao M, Li B, Yu A, Liang F, Yang L, Sun Y (2010) The effect of aeration rate on forced-aeration composting of chicken manure and sawdust. Bioresour Technol 101(6):1899-1903

Gigliotti G, Proietti P, Said-Pullicino D, Nasini L, Pezzolla D, Rosati L, Porceddu PR (2012) Co-composting of olive husks with high moisture contents: organic matter dynamics and compost quality. Int Biodeterior Biodegradation 67:8-14 
Hachicha R, Hachicha S, Trabelsi I, Woodwardb S, Mechichi T (2009) Evolution of the fatty fraction during co-composting of olive oil industry wastes with animal manure: maturity assessment of the end product. Chemosphere 75(2009):1382-1386

Haug RT (1993) The practical handbook of compost engineering. Lewis Publishers, Florida, p 213

Hu W, Zheng G, Fang D, Cui C, Liang J, Zhou L (2015) Bioleached sludge composting drastically reducing ammonia volatilization as well as decreasing bulking agent dosage and improving compost quality: a case study. Waste Manag 44:55-62

Ingelmo F, Molina MJ, Soriano MD, Gallardo A, Lapeña L (2012) Influence of organic matter transformations on the bioavailability of heavy metals in a sludge based compost. J Environ Manage 95:104-109

Kumar M, Ou WL, Lin JG (2010) Co-composting of green waste and food waste at low C/N ratio. Waste Manag 30:602-609

Lim PN, Wu TY, Sim EYS, Lim SL (2011) The potential reuse of soybean husk as feedstock of Eudrilus eugeniae in vermicomposting. J Sci Food Agric 91(14):2637-2642

Lim SL, Wu TY, Clarke C (2014) Treatment and biotransformation of highly polluted agro-industrial wastewater from a palm oil mill into vermicompost using earthworms. J Agric Food Chem 62(3):691-698

Lim PN, Wu TY, Clarke C, Daud NNN (2015a) A potential bioconversion of empty fruit bunches into organic fertilizer using Eudrilus eugeniae. Int $\mathbf{J}$ Environ Sci Technol 12(8):2533-2544

Lim SL, Wu TY, Lim PN, Shak KPY (2015b) The use of vermicompost in organic farming: overview, effects on soil and economics. J Sci Food Agric 95(6):1143-1156

Lim SL, Lee LH, Wu TY (2016) Sustainability of using composting and vermicomposting technologies for organic solid waste biotransformation: recent overview, greenhouse gases emissions and economic analysis. J Clean Prod 111:262-278

Loow YL, Wu TY, Tan KA, Lim YS, Siow LF, Md. Jahim J, Mohammad AW, Teoh WH (2015) Recent advances in the application of inorganic salt pretreatment for transforming lignocellulosic biomass into reducing sugars. J Agric Food Chem 63(38):8349-8363

Makni H, Ayed L, Ben Khedher M, Bakhrouf A (2010) Evaluation of the maturity of organic waste composts. Waste Manage Res 28:489

Muktadirul Bari Chowdhury AKM, Akratos CS, Vayenas DV, Pavlou $S$ (2013) Olive mill waste composting: a review. Int Biodeterior Biodegrad 85:108-119

Muktadirul Bari Chowdhury AKM, Michailides MK, Akratos CS, Tekerlekopoulou AG, Pavlou S, Vayenas DV (2014) Composting of three phase olive mill solid waste using different bulking agents. Int Biodeterior Biodegrad 91:66-73

Mulvaney RL (1996) Methods of soil analysis, part 3, chemical methods, nitrogen-inorganic forms, In Sparks DL (ed) SSSA Book Ser. 5. Soil Sci. Soc. Am., Madison, WI, USA; pp 1123-1184

OG (2014) The official gazette of republic of turkey. Regulations regarding the production, import, marketing and inspection of organic, organomineral fertilizers and soil amendment products and other products, microbial and enzyme based products (In Turkish). Republic of Turkey, Official Gazette, No: 28956
Paredes C, Bernal MP, Cegarra J, Roig A (2002) Bio-degradation of olive mill wastewater sludge by its co-composting with agricultural wastes. Bioresour Technol 85:1-8

Raj D, Antil RS (2011) Evaluation of maturity and stability parameters of composts prepared from agro-industrial wastes. Bioresour Technol 102(3):2868-2873

Rasapoor M, Nasrabadi T, Kamali M, Hoveidi H (2009) The effects of aeration rate on generated compost quality, using aerated static pile method. Waste Manag 29(2009):570-573

Rihani M, Malamis D, Bihaoui B, Etahiri S, Loizidou M, Assobhei O (2010) In-vessel treatment of urban primary sludge by aerobic composting. Bioresour Technol 101(15):5988-5995

Roig A, Cayuela ML, Sánchez-Monedero MA (2006) An overview on olive mill wastes and their valorisation methods. Waste Manag 26:960-969

Sánchez-Arias V, Fernández FJ, Villaseñor J, Rodríguez L (2008) Enhancing the co-composting of olive mill wastes and sewage sludge by the addition of an industrial waste. Bioresour Technol 99:6346-6353

Sánchez-Monedero MA, Roig A, Paredes C, Bernal MP (2001) Nitrogen transformation during organic waste composting by the rutgers system and its effects on $\mathrm{pH}, \mathrm{EC}$, and maturity of the composting mixtures. Bioresour Technol 78:301-308

Sellami F, Jarboui R, Hachicha S, Medhioub K, Ammar E (2008) Cocomposting of oil exhausted olive-cake, poultry manure and industrial residues of agro-food activity for soil amendment. Bioresour Technol 99:1177-1188

Şevik F (2014) Investigation of co-composting of sewage sludge with different additive materials. M.Sc. Thesis, Suleyman Demirel University, Isparta, Turkey, pp 11,12

Shak KPY, Wu TY, Lim SL, Lee CA (2014) Sustainable reuse of rice residues as feedstocks in vermicomposting for organic fertilizer production. Environ Sci Pollut Res 21(2):1349-1359

Sharma VK, Canditelli M, Fortuna F, Cornacchia G (1997) Processing of urban and agro-industrial residues by aerobic composting: review. Energy Convers Manag 38(5):453-478

Sudharsan Varma V, Kalamdhad AS (2015) Evolution of chemical and biological characterization during thermophilic composting of vegetable waste using rotary drum composter. Int J Environ Sci Technol 12:2015-2024

Tosun İ (2003) Compostability of rose processing wastes with organic fractions of municipal solid wastes, Ph.D. Thesis, Ylldı Technical University, İstanbul, Turkey

TurkStat (2013) Turkish Statistical Institute Data Basis, http://www. tuik.gov.tr

USCC (2002) Test methods for the examination of composting and composts. Thompson W. The US Composting Council: US Government Printing Office

Wei L, Shutao W, Jin Z, Tong X (2014) Biochar influences the microbial community structure during tomato stalk composting with chicken manure. Bioresour Technol 154:148-154

Wu C, Li W, Wang K, Li Y (2014a) Usage of pumice as bulking agent in sewage sludge composting. Bioresour Technol 190:516-521

Wu TY, Lim SL, Lim PN, Shak KPY (2014b) Biotransformation of biodegradable solid wastes into organic fertilizers using composting or/and Vermicomposting. Chem Eng Trans 39:1579-1584 
Zhou HB, Ma C, Gao D, Chen TB, Zheng GD, Chen J et al (2014) Application of a recyclable plastic bulking agent for sewage sludge composting. Bioresour Technol 152:329-336

Zorpas AA, Loizidou M (2008) Sawdust and natural zeolite as a bulking agent for improving quality of a composting product from anaerobically stabilized sewage sludge. Bioresour Technol 99:7545-7552
Zucconi F, de Bertoldi M (1987) Compost specifications for the production and characterization of compost from municipal solid waste. In: de Bertoldi M, Ferranti MP, L'Hermite P, Zucconi F (eds) Compost: production, quality and use. Elsevier Applied Science, Essex, pp 30-50 